\title{
Sholem Aleichem and Qumran: Jewish-Related Scholarship in the Soviet Union, 1953-1967
}

The Jewish academic centers established in the early Soviet state functioned almost exclusively in Yiddish and had eclipsed or subdued the remnants of Jewish studies pursued at academic and independent organizations of the pre-1917 period. In Kiev, the most vigorous of the new centers developed ultimately into the Institute of Jewish Proletarian Culture (IJPC), a structural unit of the Ukrainian Academy of Sciences. By 1934, the IJPC had on its payroll over seventy people in academic and administrative roles. Two years later, however, the Stalinist purges of the time had consumed the IJPC and sent many of its employees to prison to be later sentenced to death or gulag. ${ }^{1}$ In Minsk, the authorities similarly destroyed the academic Institute of National Minorities, which mainly dealt with Jewish-related research. ${ }^{2}$ By this time, all Jewish (in fact, Yiddish-language) educational institutions, including university departments, ceased to exist. Some scholars moved to other fields of research or left academia entirely. Soviet school instruction and cultural activity in Yiddish emerged in the territories of Poland, Romania, and the Baltic states, forcibly acquired in 1939 and 1940, but after June 22, 1941, all these disappeared in the smoke of World War II.

However, the IJPC had an afterlife: in the fall of 1936, the authorities permitted the formation of a small academic unit named the Bureau (kabinet) for Research on Jewish Literature, Language, and Folklore. The Bureau endured until 1949, when it fell victim to a campaign that targeted the remaining Jewish institutions. In the same year, the authorities closed the Lithuanian Jewish Museum,

Note: The research for this article was conducted as part of the Shvidler Project for the History of the Jews in the Soviet Union at New York University. I owe thanks to Lawrence H. Schiffman, Igor Krupnik, and Kirsten Howe, who helped me in conceiving and writing this article.

1 See, for example, D. Shneer, "A Study in Red: Jewish Scholarship in the 1920s Soviet Union," Science in Context 20, no. 2 (2007): 197-213; E. Melamed, "The Fate of the Archives of the Kiev Institute of Jewish Proletarian Culture: Puzzles and Discoveries," East European Jewish Affairs 42, no. 2 (2012): 99-110.

2 D. Shevelëv, "Iz istorii evrě̌skikh akademicheskikh podrazdeleny̌̆ v Belorusskoĭ Sovetskoř Soţialisticheskoĭ Respublike v 1920-kh-nachale 1940-kh gg,” in Sovetskaîa iudaika: istorîa, problematika, personalii, ed. M. Kupovetskiī (Jerusalem and Moscow: Gesharim/Mosty kul’tury, 2017), $78-79$.

Ә OpenAccess. (C) 2021 Gennady Estraikh, published by De Gruyter. (cc))BY-NC-ND This work is licensed under the Creative Commons Attribution-NonCommercial-NoDerivatives 4.0 International License. 
which was established in Vilnius soon after the city's liberation from the Germans. ${ }^{3}$ The year 1950 saw the closing of the department of Assyrian and Hebrew studies at the Oriental Faculty of the Leningrad State University. ${ }^{4}$ In Tbilisi, the Historical and Ethnographic Museum of Georgian Jews survived longer, but its turn to be phased out came in $1952 .{ }^{5}$ In that year, thirteen leading figures in the Jewish Anti-Fascist Committee (JAFC, 1942-1948) faced execution on August $12 .{ }^{6}$ In post-Stalinist Soviet Union, no institutions or programs for studying Jews and Judaism were in existence, apart from small-scale Hebrew courses and Oriental Studies at universities and research centers in Moscow, Leningrad, and Tbilisi.

The following analysis of Jewish-related scholarly life focuses on the relatively liberal stretch of years between March 1953, when Stalin's death stopped overtly anti-Jewish campaigns, and the June 1967 war in the Middle East, which created a harsher climate for Jewish life in the Soviet Union.

\section{Continuation of Interrupted Projects}

The bulk of the output produced by Yiddish-language academic institutions in the 1920s-1940s has become irrelevant to the radically changed societal, linguistic, and ideological environment of Jewish life today. However, this does not apply to the legacy of the momentous works in the field of Jewish ethnomusicology left by Moisei (Moyshe) Beregovsky (1892-1961). In 1927, Beregovsky initiated the establishment of the Commission for Jewish Folk Music Research at the Department of Jewish Culture of the Ukrainian Academy of Sciences, and, from 1929, he headed research of musical folklore at the IJPC and then-after its dismantling-at the Bureau. The purges of the 1930s spared him, but he did not avoid incarceration in the 1950s. Released from the gulag in 1955, Beregovsky returned to Kiev and, until his death, prepared his collections for publication. Although Soviet musicology generally shunned Jewish themes, the attitude to

3 D. F. Fishman, The Book Smugglers: Partisans, Poets, and the Race to Save Jewish Treasures from the Nazis (Lebanon: University Press of New England, 2017), 234-35.

4 I. Axelrod-Rubin, "The Jewish Contribution to the Development of Oriental Studies in the USSR," in Jews in Soviet Culture, ed. J. Miller (London: Transaction Books, 1984), 287-88.

5 M. Altshuler, "Georgian Jewish Culture under the Soviet Regime," Soviet Jewish Affairs 5, no. 2 (1975): 32-37.

6 See, for example, J. Rubenstein and V. P. Naumov, eds., Stalin's Secret Pogrom: The Postwar Inquisition of the Jewish Anti-Fascist Committee (New Haven: Yale University Press, 2001). 
folk music was different. ${ }^{7}$ As a result, Beregovsky's two books posthumously saw publication: in 1962, the Moscow publishing house Sovetsky kompozitor [Soviet Composer] produced his Jewish Folk Songs, edited by composer and music critic Sergey Aksiuk (1901-1994), formerly editor-in-chief of the Sovetsky kompozitor, and in 1987, the same publisher put out Jewish Folk Instrumental Music, edited by ethnomusicologist Max Goldin (1917-2009), who taught at the Conservatory of Riga.

Meanwhile, the Moscow Yiddish literary journal Sovetish Heymland [Soviet Homeland], which was started in 1961 under the editorship of the poet Aron Vergelis (1918-1999), began to play the supplementary role of an outlet, often the only one available, for publications of popular and, increasingly over the years, serious academic essays, most notably on various aspects of Yiddish philology. The journal formed a small "pale of Jewish cultural settlement," whose internal life remained barely visible even to Soviet Jews, the prevalent majority of whom could not, or would not, read the about 10,000 copies sold around the country. Yet, in addition to its role of a forum for Yiddish literature, the journal acted also as an umbrella for various projects, including the preparation of a Russian-Yiddish dictionary.

In 1948, the Kiev Bureau's dictionary manuscript, a product of many years of work, was already in the hands of the Moscow Jewish publishing house Der Emes [Truth]. However, in November of that same year, the publishing house stopped operating, as it was closed down concurrently with the liquidation of the JAFC. In January 1949, the secret police arrested Elye Spivak (1890-1950), the Bureau's director and editor-in-chief of the dictionary, and transported him to a prison in Moscow, where he would die. Two months later, Chaim Loytsker (1898-1970), a senior scholar, was also arrested and received a sentence of fifteen years of hard labor. The year 1951 saw the arrest of two other dictionary compilers, Moyshe Maidansky (1900 - 1973) and Ruven Lerner (1912-1972), both sentenced to ten years of incarceration. The logic of the selection of targets for persecution often escaped contemporaries and remains a puzzle for historians. In any case, Moyshe Shapiro (1899-1973), the leading linguist of the Bureau, was never arrested. He left Kiev to teach Russian philology at the pedagogical institute in the city of Tiraspol in Moldavia (the breakaway Transnistria territory in contemporary Moldova).

In the early 1960s, Vergelis enthusiastically supported the idea to revive the dictionary project and allocated an office space for Shapiro, who had moved to

7 J. Braun, "Jews in Soviet Music," in Jews in Soviet Culture, ed. J. Miller (London: Transaction Books, 1984), 85. 
Moscow after retiring from teaching in Tiraspol. Shapiro and other surviving linguists began revising and refocusing the dictionary, which, in its original design, was intended for users with a good knowledge of Yiddish. By the mid-1960s, it had to address a different audience, including people who wanted to learn the language or lacked the means to express the realities of modern life. In addition, it was necessary to take into account new Yiddish dictionaries published outside the Soviet Union by that time. In 1965, a reworked version was submitted to the publishing house Sovetskaya Entsiklopedia [Soviet Encyclopedia].

Shapiro and other linguists associated with the Sovetish Heymland rejected the militant purism practiced by some of their American colleagues, who were always on the warpath against etymologically "unacceptable" words. According to Shapiro, however, the German, Hebrew, or Slavic origin of the word was of less importance than its authenticity, stylistic adequacy, and clarity. Although the Sovetish Heymland toed the official Soviet line of rejecting the notion of a worldwide Jewish nation, the journal, a publication with a cultural-diplomatic mission, sought to attract foreign readers. Therefore it did not try to erect an artificial wall between the Soviet and non-Soviet varieties of Yiddish. Shapiro even doubted the value of the notion of Soviet Yiddish:

This definition never had nor could have any terminological meaning, since it never meant a new quality of a literary language different from the literary Yiddish outside the borders of the Soviet Union. In fact, there were only a few peculiarities which could justify speaking (even conditionally) of a specific Soviet Yiddish style. ${ }^{8}$

Significantly, although the journal and other Moscow Yiddish publications did not reintroduce the traditional spelling of Hebrew words, the final consonant letters, characteristic for Hebrew and non-Soviet Yiddish, reappeared in the journal after three decades of abandoning them as a result of the radical orthographic reform. ${ }^{9}$

The compilers hoped the dictionary would come out in 1967. However, the publisher's guidelines demanded serious, time-consuming improvements. At some stage, the text incorporated a clandestine epitaph to the leading figures in the JAFC executed on August 12, 1952: the combination of words "on the twelfth of August" illustrated the usage of "twelfth," although examples of usage did not accompany any other ordinal numbers. The dictionary, which final-

8 G. Estraikh, Soviet Yiddish: Language Planning and Linguistic Development (Oxford: Oxford University Press, 1999), 108-9.

9 G. Estraikh, “Soviet Yiddish Orthography: An Iron Logic or Coincidence?” Shvut 1-2 (1995): 218-41. 
ly appeared in 1984, was, in a sense, a memorial to the Soviet Yiddish linguists of the IJPC and the Bureau. None of them lived to see this publication completed by Moyshe (Moyni) Shulman (1911-1994), a retired senior editor of the Sovetish Heymland..$^{10}$

\section{Moyshe Belenky}

Moyshe (Moisei) Belenky (1910-1996) never contributed to the Sovetish Heymland, because he sought to be appointed its editor, and this competition between himself and Vergelis made them sworn enemies. While still a student himself at the Moscow Teachers Training Institute, which had a Yiddish department until 1938 and was the alma mater of many Yiddish literati, he began to teach Marxist-Leninist philosophy to students of the theater school at the Moscow State Yiddish Theater and then, in 1932-1949, he worked as the school's director. Later he combined this position with that of editor-in-chief of the publishing house Der Emes. Arrested in 1949, he was held incarcerated until 1954. Upon his release and legal rehabilitation, Belenky pursued two parallel careers, one in Jewish literary scholarship and one in philosophy (he taught at the prestigious Shchukin Theater School in Moscow), with emphasis on topics of scientific atheism. This field, propagandistic in nature though with an academic slant, received a push in 1954, when two decrees formulated a new approach to dealing with the "survivals" of religious mentality. Religion had no place in communist society of the near future as envisioned by Nikita Khrushchev, and atheism, specifically Marxist scientific atheism, should build a solid dam against it. ${ }^{11}$

Belenky was perfectly prepared to work in scientific atheism. As early as 1941, he published a Yiddish book entitled Acosta, Spinoza, and Maimonides. According to Belenky, Uriel Acosta, "one of the first critics of the Bible, gravitated to materialism," whereas Baruch Spinoza "furthered materialist examination of the world." Maimonides, or Rambam, on the other hand, fought for "the freedom of

10 W. Moskovich, "An Important Event in Soviet Yiddish Cultural Life: The New RussianYiddish Dictionary," Soviet Jewish Affairs 14, no. 3 (1984): 31-49; W. Moskovich, "The RussianYiddish Dictionary of 1984 and the Problems of the Maintenance of Soviet Yiddish after the Second World War," in Under the Red Banner: Yiddish Culture in the Communist Countries in the Postwar Era, ed. E. Grözinger and M. Ruta (Wiesbaden: Harrassowitz, 2008), 231-38; L. Fliat, "I slovar', i pamiatnik,” My zdes' 581, March 8-18, 2018, http://www.newswe.com/ index.php? go=Pages\&in=view\&id=1945.

11 J. Anderson, Religion, State and Politics in the Soviet Union and Successor States (Cambridge: Cambridge University Press, 1994), 16. 
reason, but in some philosophical issues he slipped to the positions of idealism." Belenky emphasized that he based his research on the Marxist methodology, because there was no other way to understand fully and correctly the philosophers' worldviews and their places in the history of human thought. ${ }^{12}$

The Marxist approach also implied a heavy ideological bias. In 1959, Belenky wrote that "Judaism, like any other religion, represents a conservative and reactionary worldview." Moreover, according to him, "Israeli clericals solidarize[d] with fascist cannibals-cum-racists." 13 He continued to study the three philosophers, but Spinoza and Acosta were more welcome in the Soviet ideological climate. His 1964 book, Spinoza, came out in the respected and widely read series Life of Remarkable People. In 1956, the All-Union Society for the Dissemination of Political and Scientific Knowledge published Belenky's supporting material for lectures on The Origin and Class Essence of Judaism. His pamphlet, What is the Talmud, came out in 1960, and the same title appeared again in 1963 and 1970, on the covers of his much weightier volumes.

Belenky was not, by any means, the only author writing on Judaism. Critique of Judaism played a significant role in the work of other scientific atheists, including Giler Livshits (1909-1983), a distinguished Minsk-based historian of antiquity and religion. An important figure in the field was Mikhail Shakhnovich (1911-1992), whose first book, The Social Essence of the Talmud, appeared as early as 1929. One of the founders of the Museum of History of Religion in Leningrad (St. Petersburg), Shakhnovich worked as its leading scholar. In his 1960 book, entitled The Reactionary Essence of Judaism, Shakhnovich argued that Judaism created conditions for spreading ideologies of Zionism and American imperialism, as well as for gender inequality. ${ }^{14}$ His monograph The Decline of Judaism followed in 1965. Judaism remained, however, a sideline in Shakhnovich's voluminous output. In general, in an imagined competition among scientific atheists dealing with various aspects of Jewish religion, the laurels for the most prolific author would certainly go to Belenky.

In 1960, Belenky's pamphlet The Talmud in the Light of Science appeared in Moscow. And 1962 saw the publication of his edited volume, The Critique of Judaism, which came out under the imprimatur of the History Institute at the Academy of Sciences. In his 1966 monograph Judaism, he praised the Karaites for becoming a voice of "the latent protest of Jewish masses against the inhuman

12 M. S. Belen'kiĭ, Akoste, Shpinoze, Maymon (Moscow: Der Emes, 1941), 3-4.

13 M. S. Belen'kiĭ, “O sovremennom iudaizme v SShA i Izraile,” Voprosy istorii religii i ateizma 7 (1959): 106, 115.

14 M. Shakhnovich, "Pravda o sovremennom iudaizme," Agitator 23 (1963): 52-54. 
exploitation, justified and defended by the Talmud." 15 He fired his criticism at Rabbi Yehudah Leib Levin (1894-1971) of the Moscow Choral Synagogue for preaching that Jews were provided with nitzotz elokim, the divine spark in the soul, which kept them attached to the Jewish faith. ${ }^{16}$ Conflating anti-clericalism with anti-Zionism, Belenky went on to (mis)inform his readers about the legalities of life in Israel. Thus, according to him, an uncircumcised boy could not become a citizen of the country, and a woman had limited legal rights in many spheres of Israeli life. ${ }^{17}$ (Even still, in 1990 he would settle in Rehovot, Israel.)

In 1967, the Moscow State University's Department of History and Theory of Atheism accepted his dissertation on Critical Analysis of the Dogma, Cult and Ideology of Judaism and thus effectively certified him as a top specialist. It is highly questionable, though, if his books fulfilled the claimed mission of "firmly shattering the myth of supernatural origin of Jewish religion, holidays, and rites" and "showing the reactionary nature of Judaism."18 According to Alexander Grushevoi, a historian of antiquity and the Middle East, Belenky's writings on the Talmud have little to do with scholarship. Still, he commends Belenky's work as, at that time, the only widely accessible source of information on this topic. ${ }^{19}$

\section{Literary Scholarship}

Despite the devastating losses endured by Yiddish literary circles during World War II and the Stalinist repression, the Sovetish Heymland could always rely on scores of contributors, including literary scholars. In one of his first interviews, Vergelis stated: "We are allotting much space in our magazine to problems of literary theory and criticism."20 Initially, Nokhem Oyslender (1893-1962), a central figure in Soviet Yiddish literary life from its early days, acted as the doyen of the critical guild heading the journal's department of literary criticism. However, a year after the journal was started, this position became vacant.

Hersh (Grigory) Remenik (1905-1981), Oyslender's replacement, belonged to the generation schooled during the Soviet period. He graduated from the Yiddish

15 M. Belen'kiı̆, Iudaizm (Moscow: Political Literature Press, 1966), 130.

16 Ibid., 9.

17 Ibid., 94, 222.

18 Ibid., 237-38.

19 A. G. Grushevor̆, "K istorii izucheniîa v Rossii Talmuda i perioda ego sozdaniîa," Pis’mennye pamiatniki Vostoka 1 (2007): 95.

20 S. Chertok, “A New Magazine in Yiddish,” Soviet Literature 1 (1962): 178. 
department at the Odessa Pedagogical Institute and worked as a teacher in an old Jewish agricultural colony in Ukraine. In 1934, the Yiddish department at the Moscow Pedagogical Institute admitted him as a graduate student, and in 1937, after defending his dissertation on Sholem Aleichem's novellas, he received the academic title of candidate of philological sciences. (The advanced academic degrees of "candidate" and "doctor" were introduced in the Soviet Union in 1934.) Two years later, however, Remenik was arrested. Following his liberation and legal rehabilitation, around 1955, he taught Russian literature at the pedagogical institute in Yaroslavl, an old Russian city. After moving to Moscow to replace Oyslender at the department of literary criticism, Remenik played an important role in shaping the literary-critical politics of the journal and engaging other literary specialists. In its first issue of 1966, the Sovetish Heymland reported (p. 109) that in December 1965, he had organized a "scientific session" devoted to Y. L. Peretz, marking the fiftieth anniversary of the classic writer's death.

Hillel Aleksandrov (1890 - 1972), who came to the "session" from Leningrad, began his academic career in Minsk as a specialist in social-demographic aspects of Jewish life, but in 1933, he settled in Leningrad and worked there as a professor at the Institute of History, Philosophy, and Linguistics. Arrested in 1937, he was not released until 1959 and then taught at the Oriental Faculty of the Leningrad University. He wrote in the Sovetish Heymland about his archival findings, most notably about the legacy of Israel Tsinberg (1873-1939), the preeminent historian of Jewish literature, whose death he witnessed in the gulag. ${ }^{21}$

Khatskl Nadel (1905-1968) and Oyzer Holdes (born Holdesheym, 1900 1966), came to the Peretz conference from Kharkiv. They were holdovers from the time, until 1934, when the city was the capital of Soviet Ukraine and, as such, housed Jewish cultural, educational, and publishing organizations. Both were arrested in 1951 and could return to Kharkiv only after several years in the gulag. Holdes was reinstated as a member of the Writers Union, whereas Nadel renewed his work as a bibliographer, being hailed as the founder of the local academic tradition in the field of bibliography. ${ }^{22}$ Irme Druker (19061982), an Odessa-based writer and student of literature, was also incarcerated from 1950 to 1956. His book on Mendele Moykher-Sforim, The Grandfather Mendele, came out in Yiddish in Warsaw in 1964.

21 G. Eliasberg, “...Odin iz prezhnego Peterburga”: S. L. TSinberg-istorik evreiskoi literatury, kritik i publitsist (Moscow: Russian State University for the Humanities, 2005), 146.

22 S. B. Glibitŝaîa, "Osnovatel' khar'kovskoĭ universitetskoĭ shkoly bibliografov: X. S. Nadel' (1905-1968): k 110-letiiu so dnia rozhdeniia,” Bibliotechnǐ forum: istoriia, teoriia i praktika 1 (2015): 58-60. 
In the Sovetish Heymland's "pale of literary settlement," critics and historians could analyze works by authors who were of no interest to the rest of Soviet academia. Outside the "pale," the list of Yiddish writers usually ended up where it started: Sholem Aleichem. The mini-industry that emerged in the 1920s and matured in the 1930s and the 1940s around Sholem Aleichem-related cultural activities continued to function during the last Soviet decades. ${ }^{23}$ In 1963, Remenik's biography of Sholem Aleichem, published in Russian with a print-run of 10,000 copies, gained the praise of The New York Times (17 November 1963, p. 40), which characterized the book as a "warm, sympathetic biography and literary criticism of Sholem Aleichem.” In 1972, Remenik defended a doctoral dissertation on Sholem Aleichem's oeuvre, at the Institute of World Literature. It was the only dissertation on Yiddish literature defended in the Soviet Union in the 1950s1980s. The defense became possible thanks to Uran Guralnik (1921-1989), a leading scholar of the institute and a contributor to the Sovetish Heymland.

Another reputed leading scholar on Sholem Aleichem was Riva Rubina (1906-1987), who in the 1930s lectured on the history of Yiddish literature at the Minsk Pedagogical Institute and, from 1934, at the Moscow Pedagogical Institute. Later she established herself as a compiler and commentator of Russian translations of Sholem Aleichem's writings. In the 1950s, she continued her activity, which began in 1940, when the State Publishing House produced her edited collection of stories by the classic writer. The year 1956, the fortieth anniversary of Sholem Aleichem's death, saw the publication of his stories for children edited by Rubina for the Publishing House of Children's Literature. Then in 1957, the State Publishing House put out a seven-hundred-page volume of Sholem Aleichem's prose with an introduction written by Rubina. And in 1959, the year of Sholem Aleichem's centenary, another smaller collection of his writings carried Rubina's introduction. A biographical article written by her also opened the first volume of the jubilee collection of Sholem Aleichem's works, which had a quarter of a million print-run for each of its six volumes.

The Soviet ideological apparatus saw the Sholem Aleichem centenary as a public relation, or cultural diplomatic, opportunity for showing the world that Jewish culture enjoyed full state support. In this climate, Israel Serebriani (1900 -1978), a Yiddish literary scholar, had a chance to publish his book Sholem Aleichem and Folk Creativity in Russian. Originally written in Yiddish, it was translated by Rashel Miller-Budnitskaia (1906-1967), who taught foreign literature at the Moscow Region Pedagogical Institute.

23 G. Estraikh, "Soviet Sholem Aleichem," in Translating Sholem Aleichem: History, Politics and Art, ed. G. Estraikh, J. D. Finkin, and M. Krutikov (Oxford: Legenda, 2012), 62-82. 
Belenky, ubiquitous in virtually all domains of Soviet Jewish cultural life, played a central role in the production of books by and on Sholem Aleichem. The first job that he found after his release from the gulag was at the State Publishing House of Belles-Lettres, the parent organization of the liquidated Der Emes. There, he dealt with the project of a hundred volume series of Jewish literature translated into Russian. ${ }^{24}$ This project was aborted soon after conception, but in the meantime, Belenky had secured for himself an influential place in Jewish-related publishing and was the main person responsible for compiling and editing the six-volume centenary edition of Sholem Aleichem's oeuvre.

\section{Ancient History and Philology}

It is certainly no coincidence that "history" was conspicuously absent in the name of the remnant of the IJPC-the Bureau for Research on Jewish Literature, Language, and Folklore. Publications on ethnic history were of particular concern to Soviet ideologists. Peeter Tulviste, an Estonian scholar, wrote about ethnic identity that to a significant degree it

can be conceived as consisting of various texts which interact with each other [...] From this point of view, history texts of various kinds interact with each other and many other texts in the formation as well as the functioning of individual identity. ${ }^{25}$

A Soviet Jew usually had few, if any, texts on Jewish history for her or his identity-generating interactions. Significantly, vigilant functionaries in the Communist Party's Central Committee routinely blocked publication of scholarly works devoted to the Holocaust, and the term itself did not appear in the vocabulary of Soviet books and periodicals.

Readers interested in Jewish history would look for indirect ways of getting access to information, finding it usually in occasional journalistic coverage of historical topics or in belles-letters, such as the writings of the German Jewish novelist Lion Feuchtwanger, the most broadly published German-language writer in the Soviet Union. According to the Soviet statistics for 1917-1957, his books came out in sixty editions, translated into eight languages spoken in the Soviet

24 G. Kenig, "Der 'goldener fond' fun der yidisher literatur in sovetn-farband,” Morgn-Frayhayt, October 19, 1956, 4.

25 P. Tulviste, "History Taught at School Versus History Discovered at Home: The Case of Estonia," European Journal of Psychology of Education 9, no. 2 (1994): 122-23. 
Union, with the total print run of over 2.6 million copies. ${ }^{26}$ Shimon Markish wrote the following about the Feuchtwanger phenomenon:

in the second half of the 1950s and in the 1960s his works were published in the USSR many times. All of his novels with the exception of Jephthas Tochter (Jephtha's Daughter) were published or republished within this fifteen-year period, and his collected works in twelve volumes were published in an edition of 300,000 copies. In all, this comprised a kind of compendium of Jewish history from the beginning of the Christian era to the Nazi persecutions. Most Jews of my generation and of the generation after mine experienced the fascination of Feuchtwanger, if not always as a writer at least as a Jew. ${ }^{27}$

At the same time, Soviet scholars' studies of the ancient past sometimes touched on aspects of Jewish history. Such esoteric topics were obviously considered harmless and incapable of boosting Jewish historical memory. For instance, readers had access to the 1962 book History of the Khazars by Mikhail Artamonov (1898-1972), director of the State Hermitage Museum in Leningrad. A decade before its publication, Artamonov had a difficult stretch in his life. In December 1951, he, an archeologist, was attacked in the Pravda, the central party daily newspaper, for claiming that Khazaria served as a model for Ancient Russia. ${ }^{28}$ Rumors ascribed the article, bylined "P. Ivanov," to various people, including Stalin. It was indeed a serious matter in the climate of the time, when the agitprop expected to see validation of Russia's role as a pioneer rather than an imitator. The experience of the early 1950s left an imprint on Artamonov's 1962 book, which claimed inter alia that adoption of the Jewish religion by the ruling class of Khazaria was "a fatal step," because it severed the government from the people, replaced pastoral nomadism and agriculture with mercantile middlemen, and led to the "parasitic enrichment of the ruling elite."29

This idea that the Khazar state became parasitic after accepting Judaism found further development in the work of the leading Soviet archeologist Svetlana Pletneva (1926-2008). ${ }^{30}$ Mikhail Ikhilov (1917-1998), who defended

26 C. Wachsmann, Der sowjetische Heine: Die Heinrich Heine-Rezeption in den russischsprachigen Rezeptionstexten der Sowjetunion (1917-1953) (Berlin: Weißensee, 2001), 2.

27 S. Markish, "The Role of Officially Published Russian Literature in the Reawakening of Jewish National Consciousness (1953-1970)," in Jewish Culture and Identity in the Soviet Inion, ed. Y. Ro'i and A. Beker (New York: New York University Press, 1991), 227-28.

28 P. Ivanov, “Ob odnoĭ oshibochnoĭ konťseptsii," Pravda, December 25, 1951, 3.

29 Artamonov's 1962 book was also criticized by some historians-see, for example, Ia. A. Fëdorov's review in Voprosy istorii 3 (1963): 146-50.

30 P. B. Golden, "Khazar Studies: Achievements and Perspectives," in The World of the Khazars: New Perspectives. Selected Papers from the Jerusalem 1999 International Khazar Colloquium, ed. 
his dissertation on history and culture of Mountain (or Caucasus) Jews at the Moscow Institute of Ethnography in 1949, wrote about Khazars' involvement in the ethnogenesis of Mountain Jews. In his treatment of the subject, some of the Khazars were assimilated by the core group of Jews who had come to the Caucasus from Persia. ${ }^{31}$

1951 saw the revival of the Palestinian Society, whose roots stemmed from the Imperial Orthodox Palestinian Society, established in 1882. Although the revitalized society functioned under the auspices of the Academy of Sciences, its mission was predominantly in the domain of politics. In January 1962, Armand Volkov, the Jerusalem-based representative of the Palestinian Society and himself an orientalist scholar, visited the Central Rabbinical Library of Israel. He promised to organize exchange of publications and said that there was room for visits to the Soviet Union by Israeli academics. ${ }^{32}$ In June 1962, Zvi Harkavy (1908-1979), director of the Central Rabbinical Library, returned from a visit, lasting several weeks, to libraries of Moscow and Leningrad. It was a visit to the country where Harkavy was born and spent the first two decades of his life. He brought an agreement with the Leningrad State Public Library (from 1992, the National Library of Russia), permitting Israeli researchers to receive copies of Hebrew manuscripts. ${ }^{33}$

The Palestinian Society's journal, Palestinskii sbornik [Palestine Miscellany], became an important outlet for academic publications. No mention of the State (or pre-state period) of Israel would appear in its pages, but the taboo did not apply to medieval history of Jews and to ancient Israel. Professor Isaac Vinnikov (1897-1973), one of the semitologists who contributed to the journal, headed the department of Assyrian and Hebrew studies at the Leningrad University's Oriental Faculty in 1945-1949 and returned to the university after the forced hiatus in the late Stalinist years. At the 25th International Congress of Orientalists held in Moscow in August 1960, Vinnikov chaired the session addressed by Yigal Yadin, a general turned well-known archaeologist, one of the twelve members of the Israeli delegation. Vinnikov emphasized the importance of applying Marxist meth-

P. B. Golden, H. Ben-Shammai, and A. Róna-Tas (Leiden: Brill, 2007), 34; L. S. Klejn, Soviet Archaeology: Trends, Schools, and History (Oxford: Oxford University Press, 2012), 304.

31 M. Ikhilov, Narodnosti lezginskor gruppy (Makhachkala: The Dagestan Branch of the Academy of Sciences, 1967), 149-52.

32 "Head of Russian Palestine Society Visits Hechal Shlomo," Jerusalem Post, January 5, 1962, 3. 33 "Israeli Scientists Will Attend Red Parley," The Sentinel, June 28, 1962, 8. 
ods to biblical studies, which meant to look into social and economic context of biblical texts through the prism of classics of socialist theories. ${ }^{34}$

The Palestinskii sbornik published articles by the well-established scholar in Arabic, Aramaic, and Talmudic studies, Iulii (Iudel) Solodukho (1877-1963), whose research focused on the Babylonian Talmud but was categorized as studies of ancient Iraq and Iran. The purges miraculously bypassed Solodukho, despite the fact that in his youth, before turning into a Soviet orientalist, he was involved in rather "questionable" activities: he studied at the famed Volozhin yeshiva, was a delegate at the Fifth Zionist Congress, and participated in the Hebrew language movement. According to the American scholar of Judaism Jacob Neusner, Solodukho "made the effort both to preserve the traditions of Talmud learning acquired in his youth and to master and make use of the Marxist hermeneutic which came to dominance in his mature years." 35

Less fortunate was Iosif Amusin (1910 -1984), a specialist in the history of the ancient Near East, who, as a member of a Zionist youth organization, lived through the experience of exile, 1926-1930, and incarceration, 1938-1939. Still, he graduated from the Leningrad University and served in the army during World War II. After 1945, he taught ancient history at the Leningrad Pedagogical Institute and the Leningrad University until he was fired during the campaign against "cosmopolitanism." After a period of unemployment, he found a job at the Pedagogical Institute in the Volga city of Ulianovsk. Upon returning to Leningrad in 1954, Amusin worked as a research fellow at the Institute of Archaeology and the Institute of Oriental Studies of the Soviet Academy of Sciences and showed great interest in the Dead Sea, or Qumran, scrolls. ${ }^{36}$

The first Soviet semitologist's article on the Dead Sea scrolls, written by Amusin's colleague Klavdia Starkova (1915-2000), appeared in 1958 in the journal Vestnik drevnei istorii [Bulletin of Ancient History]. Boris Smolar, editor-inchief emeritus of the Jewish Telegraphic Agency (in the 1920s, he represented the JTA in Moscow and continued to keep a close eye on the situation in the Soviet Union), wrote about Starkova in 1969 after visiting Leningrad: “a Russian

34 "Voprosy drevneĭ istorii i filologii na 25-om mezhdunarodnom kongresse vostokovedov v Moskve," Vestnik drevnei istorii 2 (1961): 143-64.

35 I. Solodukho, Soviet Views of Talmudic Judaism: Five Papers by Yu. A. Solodukho in English Translation, ed. J. Neusner (Leiden: Brill, 1973), ix.

36 L. N. Gluskina, "The Life and Work of Joseph Amussin,” Revue de Qumrân 14, no. 1 (1989): 109-20; Ta. V. Vasil'kov, A. M. Grishina, and F. F. Perchenok, "Repressirovannoe vostokovedenie: vostokovedy, podvergshiesia repressiiam v 20-50-e gody,” Narody Azii i Afriki 4 (1990): 116. 
woman who has a record in the scholarly world as being dedicated to the study of the history of the Jewish people."37

However, semitologists were not the only scholars interested in the Dead Sea scrolls. Giler Livshits' The Qumran Scrolls and Their Historical Significance, the first pamphlet-sized description of the findings made in the Qumran gorge of the Dead Sea, was published in 1959 under the imprint of the Belorussian State University, where the author worked from 1958. In 1967, he put out a much more substantial volume, The Origin of Christianity in the Light of the Dead Sea Scrolls. Livshits' 1957 book, The Class Struggle in Judea and Uprisings against Rome, which essentially historicized biblical events and characters, had been a cause of concern to his dogmatic colleagues, who went as far as to insist on destroying the entire print run. Ultimately, the book reached readers thanks to enthusiastic reviews by influential Moscow historians. Still, a chapter on the Jewish diaspora of that time saw publication only a quarter of century after Livshits' death. ${ }^{38}$

While scholars turned to studying the Dead Sea scrolls exclusively, or at least primarily, for purely academic interest, the Soviet ideological watchdogs welcomed such studies for a completely different reason, highlighted, for instance, in a review of the 1960 book Scrolls of the Dead Sea by history popularizer Anatoly Varshavsky (1920-1990). Scientific atheists could use the dating (long before Jesus), provenance, and content of the scrolls for arguing that the official history of Christianity and, by extension, of other religions represented "an enormous falsification." "39 As a result, Varshavsky's book came out in 50,000 copies under the imprint of the Molodaia gvardiia [Young (Communist) Guard], one of the biggest Moscow publishing houses. Also in 1960, the Moscow Publishing House of Political Literature put on the market the book Finds in the Judean Desert co-authored by Sergei Kovalev (1886-1960), director of the Museum of Religion and Atheism, and Mikhail Kublanov (1914-1998), a historian of religion. This book had a print run of 55,000. Its revised edition, followed in 1964, had even a bigger print run-68,000.

Kovalev and Kublanov, as well as some other Soviet historians, impugned one of the previously unquestionable postulates of Soviet historiography of early Christianity, namely that the birthplace of the new religion located outside Palestine. The postulate originated from Friedrich Engels's statement:

37 B. Smolar, "Russia Today," Jewish Advocate, January 2, 1969, 7.

38 G. Livshits, Giler Markovich Livshits: K 100-letiiu so dnia rozhdeniia, ed. V.A. Fedosik et al. (Minsk: Belorussian State University, 2009).

39 M. Andreev, "Rukopisi Mërtvogo morîa," V mire knig 3 (1961): 6. 
The legend that Christianity arose ready and complete out of Judaism and, starting from Palestine, conquered the world with its dogma already defined in the main and its morals, ... can continue to vegetate only in the theological faculties and with people who wish "to keep religion alive for the people" even at the expense of science. ${ }^{40}$

Alexander Kazhdan (1922-1997), a Soviet Byzantinologist who had been publishing studies on the Dead Sea scrolls since the 1950s, argued that the whole massive tradition of Marxist scholars' assertion that Christianity was born in Asia Minor, not in Palestine, stemmed from misinterpretations of Engels's original writings. Kazhdan, who consequently emigrated from the Soviet Union and worked as an academic in the United States, also came to the cautiously phrased conclusion that Jesus was a historical person. ${ }^{41}$

Although Starkova, who pioneered study of Qumran in the Soviet Union, continued to publish on this theme, Amusin's works would dominate the Soviet book market. His book The Dead Sea Scrolls came out in Moscow in two editions, in 1960 and 1961. In 1962, it appeared in a Slovak translation; translations into Polish and Romanian followed in $1963 .^{42}$ In 1965, Amusin was awarded a doctorate for this research. At the award ceremony, he concluded his speech with a quote, in Hebrew, from the Pirkei Avot, a tractate that contains sayings and ethical teachings of the rabbinic sages: "You are not expected to finish the job, but you cannot shirk the obligation to undertake it. ${ }^{, 43}$ In the same year, the Moscow publishing house Nauka (Science) put out 60,000 copies of Amusin's new book, Finds at the Dead Sea, edited by Vasily Struve (1889-1965), the founder of the Soviet school of historical research of Ancient Orient. In his introduction, one of his last written works, Struve referred to Engels's recommendation to study the historical conditions which led to the rise of Christianity. In other words, he emphasized that Amusin's work was useful from the point of view of Marxist scholarship.

Amusin's books continued to appear in the coming years, even after 1967, when a vigilant eye might deem the topic of Qumran ideologically harmful, being, at least geographically, "too close" to Zionism. His paper, prepared for

40 K. Marx and F. Engels, K. Marx and F. Engels on Religion (Moscow: Foreign Languages Publishing House, 1957), 321.

41 D. V. Pospielovsky, Soviet Antireligious Campaigns and Persecutions (Basingstoke: Macmillan, 1988), 6-7; O. V. Metel, "Sovetskaîa istoriografiīa pervonachal'nogo khristianstva v kontse 50-60-kh gg XX v.,” Vestnik Omskogo universiteta 4 (2007): 107-11.

42 Z. J. Kapera, “A Bibliography of J. D. Amussin: Concerning the Dead Sea Scrolls," Revue de Qumrân 14, no. 1 (1989): 121-26.

43 N. Shraga, "Soviet Jew Gets Ph.D. for Thesis on Jewish Subjects," The Jerusalem Post, June 22, 1965, 3. 
the 27th International Congress of Orientalists held in Ann Arbor in August 1967, was circulated and reviewed, though he did not attend the event. The Soviets, as well as Czechoslovaks, Bulgarians, and East Germans had decided to withdraw at the last moment, due to the current international situation-the war in Vietnam and the tensions in the Middle East-which made the time inopportune for cultural and scholarly exchange. ${ }^{44}$

\section{Israel Studies}

By either their own choice or the decision of some policy-makers, Leningrad semitologists were little involved in Israel-related studies or cultural projects. True, Lev (Arye Chaim Leyb) Vilsker (1919-1988), Amusin's brother-in-law, who graduated from the Leningrad University in 1950 as a specialist in semitology and worked at the Public Library, did numerous literary translations from Hebrew, signing them "Vilsker-Shumsky." Shumsk-now a town in the Ternopol region of Ukraine-was his birthplace. His translations of contemporary literary works appeared in the 1960s, when Moscow publishers had released four books of Russian translation of Israeli authors. One of them, the 1966 collection of novellas written originally in Hebrew, Arabic, and Yiddish carried the title Searchers of Pearls. It came out under Vilsker's editorship.(In the 1980s, Vilsker would publish his research articles in the Sovetish Heymland, most notably on unknown poems of Yehuda Halevi.)

Nonetheless, the establishment of the State of Israel had necessitated training of people specifically for the Ministry of Foreign Affairs and other Soviet agencies. Joseph Braginsky (1905-1989), a well-known Soviet Orientalist, encouraged Feliks (Fayvl) Shapiro (1879-1961) to work as a teacher of Hebrew. He knew Shapiro, because many years ago their fathers taught at the same Jewish school in Baku. Shapiro also had experience teaching Hebrew but later changed his profession. Now, retired, he was happy to return to Hebrew, the more so as it filled his life with interest and brought additional income.

In 1954, Shapiro threw himself, body and soul, into the work over a HebrewRussian dictionary. Israeli radio programs helped him to reflect the contemporary language usage. For the same purpose, he asked Shmuel Minunis, the head of the Communist Party of Israel, who visited Shapiro at home, to send

44 “Orientalists Begin Meeting in Michigan,” The New York Times, August 14, 1967, 6; Z. J. Kapera, "The Qumran Commentaries and their Significance for the History of the Qumran Community by Joseph Amusin,” Revue de Qumrân 6, no. 4 (1969): 590 - 92. 
him a Hebrew newspaper, the Communist Party's Kol Haam (Voice of the People). Shapiro's death in 1961 delayed the publication of the dictionary, however. Two people played decisive roles in preparing the publication afterwards: Abraham Rubinshtein (d. 1981), a former Jewish actor and later a lecturer of Hebrew at Moscow universities, and Bentsion Grande (1891-1974), a leading Soviet semitologist. Grande wrote an overview of Hebrew grammar for this edition. ${ }^{45}$ In large part thanks to this dictionary, the word ivrit (Hebrew) increasingly appeared in Soviet publications. Cleary, the term drevneevreiskii iazyk [Old Jewish language], used in Russian-language literature, could no longer be used to denote the Hebrew spoken in contemporary Israel. ${ }^{46}$

In 1964, Tbilisi hosted the first Conference on Semitic languages, with papers on ancient and modern Hebrew. The choice of the place was not random: the Tbilisi University had a department of Semitic studies at the Faculty of Oriental Studies. In 1960, the founder and head of the department, the distinguished orientalist Giorgi V. Tsereteli (1904-1973), was allowed to establish the Institute of Oriental Studies at the university. Shapiro and Rubinshtein took part in the Tbilisi conference with papers on the contemporary lexis of Hebrew. Michael Zand (b. 1927), a Moscow orientalist whose main expertise was in the Persian and Tajik languages and cultures, spoke on Yiddish as a substrate of contemporary Hebrew. ${ }^{47}$ (A decade later, Zand's struggle for emigration to Israel won the support of academicians in the Unites States and other countries.)

In Moscow, the academic Institute of Oriental Studies had scholars specializing in Israel studies. In 1953, one of them, Galina Nikitina (1924-1982), defended a candidate dissertation, on the basis of which she wrote her 1956 book The Suez Canal-the National Asset of the Egyptian People. The idea that Israel had revealed itself as an aggressive outpost of the USA was central in her 1958 article "Israel and American Imperialism." ${ }^{48}$ Economic and political expansion of Israel in Africa, a popular topic in the Soviet press, was also discussed in academic publications, notably in Nikitina's 1963 article in the scholarly journal Peoples

45 “1962, Moskve, ivrit-rusish verterbukh," Sovetish Heymland 5 (1962): 104; L. Prestina and F. L. Shapiro, Slovar' zapreshchennogo iâzyka: 125-letiiu F. L. Shapiro (Minsk: MET, 2005), 18, 20 -22, 175; Iu. I. Kostenko, "Prepodavanie ivrita v MGIMO," Iazyk ivrit: issledovanie i prepodavanie 43 (Moscow: Sefer, 2012), 102-4.

46 A. Iu. Aǐkhenval'd, Sovremennyı̆ ivrit (Moscow: Nauka, 1990), 8-9.

47 M. Agranovskaî, Evrei v Rossii: istoriograficheskie ocherki 2-ia polovina XIX veka-XX vek (Moscow: Jewish University, 1994), 173.

48 G. S. Nikitina, “Izrail' i amerikanskii imperializm,” Sovetskoe vostokovedenie 5 (1958): 71-79. 
of Asia and Africa. ${ }^{49}$ Judging by her publications, she could not read Hebrew sources and relied on translations and publications in English. Her 1968 book The State of Israel: A Historical Economic and Political Study (which also came out in Polish and English and shaped her 1977 doctoral dissertation-the first Soviet doctoral dissertation on Israel) would set a tone for academic endeavors in this field..$^{50}$ Some contemporary authors find parallels between Nikitina's analysis and the later theories of the Israeli "new historians" and "critical sociologists," particularly in rejecting the claims that Jewish-Israeli history represented a continuous national history, starting with the biblical era and going on unbroken until the establishment of the State of Israel..$^{51}$

\section{Conclusion}

As part of the strategy aimed at assimilation of Jews to the dominant culture, the ideological apparatus of the Soviet Union could consider its strategy of restricting and deforming Jewish-related academic and popular scholarship publications a success. This strategy had contributed to depriving the vast majority of Soviet Jews of cultural memory. To them, Jewish history was a virtual blank. Few people had access to books, including ones brought overtly or covertly from abroad, which could satisfy their curiosity and contribute to fostering their national pride and identity. Suppression of cultural memory by applying a straightjacket or an outright ban to works on ethnic history was seen as a way to dispel the rising tide of emigration, which would become especially strong in the 1970s, but began to spread, in particular, following the late 1950s repatriation of over 18,000 Jews to Poland and their (in the vast majority of cases) subsequent emigration to Israel. ${ }^{52}$

In reality, however, this cultural "awakening" was not the only or the main driving force of the Jewish emigration in the last decades of the Soviet Union. A more potent factor was the glass ceiling facing Jews in society, limiting their educational, social, and professional mobility, especially after 1967. As Mikhail (or Michael, as he later became known) Zand wrote soon after arriving in Israel,

49 G. S. Nikitina, “Ėkspansiia Izrailiâ v Afriku i neokolonializm,” Narody Azii i Afriki 3 (1963): $36-44$.

50 V. V. Bol'shakov, "Kritika sionizma v sovetskoĭ istoriografii,” Voprosy istorii 9 (1973): 78-88. 51 A. D. Ėpshteïn and S. A. Kozheurov, Rossiia i Izrail': trudnyi put' navstrechu (Jerusalem and Moscow: Gesharim/Mosty kul'tury, 2011), 29-33.

52 G. Estraikh, "Escape through Poland: Soviet Jewish Emigration in the 1950s," Jewish History 31, no. 3-4 (2018): 291-317. 
"every [Soviet] Jew, except the genius, knows there are certain positions he can never occupy and that he cannot hope to rise to the top."53 At play were also other non-cultural and often "non-Jewish" factors motivating Jews to leave, most notably the general disillusionment with the Soviet system. In other words, social and economic circumstances had almost nullified the "achievements" of cultural assimilation policies.

In a cruel sense, however, the oppressive policies against studies of Jews and Judaism was not completely ineffective. It certainly had a devastating effect on the state of Jewish studies in the country. In 1987, Igor Krupnik, a leader of the independent Jewish Historical and Ethnographic Commission in Moscow, listed Jewish history and philology among the most neglected areas of study. ${ }^{54}$ Apart from semitology, which had a more or less natural intergenerational transfer of knowledge, ${ }^{55}$ virtually all branches in the field of studies of Jews and Judaism had to be established anew in the 1990s. The independent, grassroots research groups, which appeared in Moscow and Leningrad in the early 1980s, left little trace in Russian academia, because the majority of their participants, many of them refuseniks, left the country in the late 1980s or in the 1990s and continued their studies in Israel or the United States. ${ }^{56}$ As a result, more often than not, Jewish studies in Russia and other post-Soviet states still struggle to this day to put down roots through the layers of wasteland left from the Soviet period.

Gennady Estraikh is a Professor at Skirball Department of Hebrew and Judaic Studies, New York University. His research and publications are mainly in the fields of Yiddish studies, and intellectual history of Jewish socialism and communism. His most recent monograph is Transatlantic Russian Jewishness: Ideological Voyages of the Yiddish Daily Forverts in the First Half of the Twentieth Century (2020).

53 M. Zand, “A Reply to Mr. Davies,” The New York Times, December 6, 1971, 39.

54 I. Krupnik, "The Contribution of the Younger Generation of Soviet Scholars to Jewish Studies in the USSR," Soviet Jewish Affairs 17, no. 2 (1987): 45.

55 I. R. Tantlevskiǐ, "Il'îa Sholeǐmovich Shifman (1930-1990)," in Il'ia S. Shifman, Karfagen (St. Petersburg: St. Petersburg University Press, 2006), 3-6; S. Iakerson, "'Ta ostalsiâ v Leningrade, chtoby stat' gebraistom,," in Sovetskaia iudaika: istoriia, problematika, personalii, ed. M. Kupovetskiì (Jerusalem and Moscow: Gesharim/Mosty kul'tury, 2017), 273-85.

56 I. Krupnik, "Kak my zanimalis' istoriě̌... i ètnografiě̌: K 35-letiîu Evrěskoĭ istoriko-ètnograficheskoĭ komissii, 1981-1990 gg," in Sovetskaîa iudaika: istoriia, problematika, personalii, ed. M. Kupovetskiǐ (Jerusalem and Moscow: Gesharim/Mosty kul'tury, 2017), 286-360; M. Beizer, "Jewish Studies Underground in Leningrad in the 1980s," East European Jewish Studies 48, no. 1 (2018): 56-77. 


\section{Bibliography}

Agranovskaīa, Marina. Evrei v Rossii: istoriograficheskie ocherki 2-īa polovina XIX veka-XX vek. Moscow: Jewish University, 1994. [Russian]

Aĭkhenval'd, Aleksandra IU. Sovremenny̌ ivrit. Moscow: Nauka, 1990. [Russian]

Altshuler, Mordechai. "Georgian Jewish Culture under the Soviet Regime." Soviet Jewish Affairs 5, no. 2 (1975): 21-39.

Anderson, John. Religion, State and Politics in the Soviet Union and Successor States. Cambridge: Cambridge University Press, 1994.

Andreev, M. "Rukopisi Mërtvogo moria." V mire knig 3 (1961). [Russian]

Axelrod-Rubin, Inessa. "The Jewish Contribution to the Development of Oriental Studies in the USSR.” In Jews in Soviet Culture, edited by Jack Miller, 243-312. London: Transaction Books, 1984.

Beizer, Michael. “Jewish Studies Underground in Leningrad in the 1980s.” East European Jewish Studies 48, no. 1 (2018): 56-77.

Belen'kiĭ, Moshe S. Akoste, Shpinoze, Maymon. Moscow: Der Emes, 1941. [Yiddish]

Belen'kiĭ, Moshe S. Iudaizm. Moscow: Political Literature Press, 1966.

Belen'kiĭ, Moshe S. "O sovremennom iudaizme v SSHA i Izraile." Voprosy istorii religii $i$ ateizma 7 (1959). [Russian]

Bol'shakov, Vladimir V. “Kritika sionizma v sovetskoǒ istoriografii." Voprosy istorii 9 (1973): $78-88$.

Braun, Joachim. "Jews in Soviet Music." In Jews in Soviet Culture, edited by Jack Miller, 65-106. London: Transaction Books, 1984. [Russian]

Chertok, S. “A New Magazine in Yiddish.” Soviet Literature 1 (1962): 176-81.

Eliasberg, Galina. “...Odin iz prezhnego Peterburga”: S.L. TSinberg-istorik evreiskoí literatury, kritik i publitsist. Moscow: Russian State University for the Humanities, 2005. [Russian]

Ėpshteìn, Alek D., and Stanislav A. Kozheurov. Rossiia i Izrail': trudnyi put' navstrechu. Jerusalem and Moscow: Gesharim/Mosty kul'tury, 2011. [Russian]

Estraikh, Gennadiy. "Escape through Poland: Soviet Jewish Emigration in the 1950s." Jewish History 31, no. 3-4 (2018): 291-317.

Estraikh, Gennadiy. "Soviet Sholem Aleichem." In Translating Sholem Aleichem: History, Politics and Art, edited by Gennadiy Estraikh, Jordan D. Finkin, Kerstin Hoge, and Mikhail Krutikov, 62-82. Oxford: Legenda, 2012.

Estraikh, Gennadiy. Soviet Yiddish: Language Planning and Linguistic Development. Oxford: Oxford University Press, 1999.

Estraikh, Gennadiy. "Soviet Yiddish Orthography: An Iron Logic or Coincidence?” Shvut 1-2 (1995): $218-41$.

Fëdorov, Takov A. “M. I. Artamonov. Istoriía khazar.” Voprosy istorii 3 (1963): 146-50. [Russian]

Fliat, Leonid. “I slovar’, i pamiatnik.” My zdes' 581, March 8-18, 2018. http://www.newswe.com/ index.php?go=Pages\&in=view\&id=1945. [Russian]

Fishman, David E. The Book Smugglers: Partisans, Poets, and the Race to Save Jewish Treasures from the Nazis. Lebanon: University Press of New England, 2017. 
Glibițkaia Svetlana B. "Osnovatel' khar'kovskoǐ universitetskoǐ shkoly bibliografov: X. S. Nadel' (1905-1968): k 110-letiîu so dnía rozhdeniía.” Bibliotechniĭ forum: istoriía, teoriia i praktika 1 (2015): 58-60. [Russian]

Gluskina, N. L. "The Life and Work of Joseph Amussin." Revue de Qumrân 14, no. 1 (1989): 109-20.

Golden, Peter B. "Khazar Studies: Achievements and Perspectives." In The World of the Khazars: New Perspectives: Selected Papers from the Jerusalem 1999 International Khazar Colloquium, edited by Peter B. Golden, Haggai Ben-Shammai, and András Roná-Tas, 7-57. Leiden: Brill, 2007.

Grushevoľ, A. G. “K istorii izucheniīa v Rossii Talmuda i perioda ego sozdaniía." Pis'mennye pamiatniki Vostoka 1 (2007): 87-99. [Russian]

TAkkerson, S. “'TA ostalsiâ v Leningrade, chtoby stat' gebraistom'.” In Sovetskaía iudaika: istoriia, problematika, personalii, edited by M. Kupovetskiĭ, 273-85. Jerusalem and Moscow: Gesharim/Mosty kul'tury, 2017. [Russian]

Ikhilov, M. M. Narodnosti lezginskor gruppy. Makhachkala: The Dagestan Branch of the Academy of Sciences, 1967. [Russian]

Ivanov, P. I. "Ob odnoǐ oshibochnoǐ konțeptŝii." Pravda, December 25, 1951. [Russian]

Kapera, Zdzisław J. "A Bibliography of J. D. Amussin: Concerning the Dead Sea Scrolls.” Revue de Qumrân 14, no. 1 (1989): 121-26.

Kapera, Zdzisław J. "The Qumran Commentaries and their Significance for the History of the Qumran Community by Joseph Amusin." Revue de Qumrân 6, no. 4 (1969): 590-92.

Kenig, G. "Der 'goldener fond' fun der yidisher literatur in sovetn-farband.” Morgn-Frayhayt, October 19, 1956. [Yiddish]

Klejn, Leo S. Soviet Archaeology: Trends, Schools, and History. Oxford: Oxford University Press, 2012.

Kostenko Tu. I. "Prepodavanie ivrita v MGIMO.” Tazyk ivrit: issledovanie i prepodavanie 43. Moscow: Sefer, 2012. [Russian]

Krupnik, Igor. "The Contribution of the Younger Generation of Soviet Scholars to Jewish Studies in the USSR." Soviet Jewish Affairs 17, no. 2 (1987): 35-48.

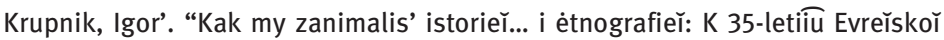
istoriko-ètnograficheskoǐ komissii, 1981-1990 gg.” In Sovetskaîa iudaika: istoriia, problematika, personalii, edited by M. Kupovetskiĭ, 286-360. Jerusalem and Moscow: Gesharim/Mosty kul'tury, 2017. [Russian]

Livshits, Giler Markovich. Giler Markovich Livshits: K 100-letiiu so dnīa rozhdeniia. Edited by V. A. Fedosik et al. Minsk: Belorussian State University, 2009. [Belo-Russian]

Markish, Shimon. "The Role of Officially Published Russian Literature in the Reawakening of Jewish National Consciousness (1953-1970)." In Jewish Culture and Identity in the Soviet Union, edited by Yaakov Ro'i and Avi Beker, 208-31. New York: New York University Press, 1991.

Marx, Karl, and Friedrich Engels. K. Marx and F. Engels on Religion. Moscow: Foreign Languages Publishing House, 1957.

Melamed, Efim. "The Fate of the Archives of the Kiev Institute of Jewish Proletarian Culture: Puzzles and Discoveries." East European Jewish Affairs 42, no. 2 (2012): 99-110.

Metel, Olga V. "Sovetskaīa istoriografiīa pervonachal'nogo khristianstva v kontse 50-60-kh gg XX v.” Vestnik Omskogo universiteta 4 (2007): 107-11. [Russian] 
Moskovich, Wolf. "An Important Event in Soviet Yiddish Cultural Life: The New Russian-Yiddish Dictionary." Soviet Jewish Affairs 14, no. 3 (1984): 31- 49.

Moskovich, Wolf. "The Russian-Yiddish Dictionary of 1984 and the Problems of the Maintenance of Soviet Yiddish after the Second World War." In Under the Red Banner: Yiddish Culture in the Communist Countries in the Postwar Era, edited by Elvira Grözinger and Magdalena Ruta, 231-38. Wiesbaden: Harrassowitz, 2008.

N. N. “1962, Moskve, ivrit-rusish verterbukh.” Sovetish Heymland 5 (1962). [Yiddish]

N. N. "Head of Russian Palestine Society Visits Hechal Shlomo." Jerusalem Post, January 5 , 1962.

N. N. "Israeli Scientists Will Attend Red Parley." The Sentinel, June 28, 1962.

N. N. "Orientalists Begin Meeting in Michigan." The New York Times, August 14, 1967.

N. N. "Voprosy drevner istorii i filologii na 25-om mezhdunarodnom kongresse vostokovedov v Moskve." Vestnik drevnei istorii 2 (1961): 143-64. [Russian]

Nikitina, G. S. “Ėkspansiía Izrailia v Afriku i neokolonializm.” Narody Azii i Afriki 3 (1963): 36-44. [Russian]

Nikitina, G. S. “Izrail’ i amerikanskii imperializm.” Sovetskoe vostokovedenie 5 (1958): 71-79. [Russian]

Pospielovsky, Dmitriy V. Soviet Antireligious Campaigns and Persecutions. Basingstoke: Macmillan, 1988.

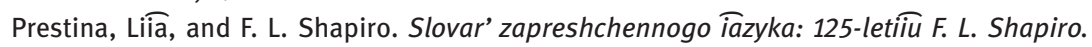
Minsk: MET, 2005. [Russian]

Rubenstein, Joshua, and Vladimir Naumov, eds. Stalin's Secret Pogrom: The Postwar Inquisition of the Jewish Anti-Fascist Committee. New Haven: Yale University Press, 2001. Shakhnovich, Marianna. "Pravda o sovremennom iudaizme." Agitator 23 (1963). [Russian] Shevelëv, Dmitriĭ. "Iz istorii evreǐskikh akademicheskikh podrazdeleny̌̃ v Belorusskoǐ Sovetskoǐ Soțialisticheskoǐ Respublike v 1920-kh-nachale 1940-kh gg.” In Sovetskaīa iudaika: istoriia, problematika, personalii, edited by M. Kupovețkiī, 78-79. Jerusalem and Moscow: Gesharim/Mosty kul'tury, 2017. [Russian]

Shneer, David. "A Study in Red: Jewish Scholarship in the 1920s Soviet Union." Science in Context 20, no. 2 (2007): 197-213.

Shraga, N. "Soviet Jew Gets Ph.D. for Thesis on Jewish Subjects." The Jerusalem Post, June 22, 1965.

Smolar, B. "Russia Today." Jewish Advocate, January 2, 1969.

Solodukho, I. A. Soviet Views of Talmudic Judaism: Five Papers by Yu. A. Solodukho in English Translation. Edited by Jacob Neusner. Leiden: Brill, 1973.

Tantlevskiĭ, Igor' R. "Il'ia Sholeimovich Shifman (1930-1990)." In Karfagen, edited by Il'ia S. Shifman, 3-6. St. Petersburg: St. Petersburg University Press, 2006. [Russian]

Tulviste, Peeter. "History Taught at School Versus History Discovered at Home: The Case of Estonia.” European Journal of Psychology of Education 9, no. 1 (1994): 121-26.

Vasil'kov, Ia. V., A. M. Grishina, and F. F. Perchenok. "Repressirovannoe vostokovedenie: vostokovedy, podvergshiesia repressiiam v 20-50-e gody." Narody Azii i Afriki 4 (1990): 113-25. [Russian]

Wachsmann, Constanze. Der sowjetische Heine: Die Heinrich Heine-Rezeption in den russischsprachigen Rezeptionstexten der Sowjetunion (1917-1953). Berlin: Weißensee, 2001.

Zand, M. “A Reply to Mr. Davies.” The New York Times, December 6, 1971, 39. 